\title{
The Impact of Medical Tourist Relationship Management Dimensions on Innovation Capabilities
}

\author{
Fayez Shriedeh \\ College of Hospitality and Tourism, Luminus Technical University College (LTUC) \\ P.O.Box 183334, Amman 11118, Jordan
}

Tel: 962-797-188-993Ｅ-mail: F.Shriedeh@1tuc.com

Received: June 21, 2019 Accepted: July 5, 2019 Published: July 19, 2019

doi:10.5296/ber.v9i3.14955 URL: https://doi.org/10.5296/ber.v9i3.14955

\begin{abstract}
This study investigates the one-to-one effect of medical tourist relationship management on innovation capabilities. This study employed regression analysis to test the research hypotheses in a sample of 306 medical tourists in Amman, Jordan. The findings indicate that long- term relationship and joint problem solving have positive impacts on all types of innovation. Knowledge management and customer involvement have positive influences on the product, process, service, and marketing innovations. Technology-based CRM has positive impacts on product, service, and process innovation. Finally, this paper discusses practical implications and future study directions.
\end{abstract}

Keywords: Customer relationship management, Innovation capability, Medical tourism, Jordan

\section{Introduction}

Medical tourism is among the fastest growing service industries in the globe. According to Ile and Tigu (2017), global medical tourism is expected to reach more than USD 3 trillion in 2025 and is expected to create more than 300 million jobs at the end of 2020 (Noor, 2013). In Jordan, medical tourism is one of the main contributors to the Jordanian economy, adding USD 1.2 billion to the GDP in 2015 (PHA, 2016) and is expected to generate revenues of around USD 2 billion in 2020 (Farkouh, 2015). According to Shriedeh (2018), Jordanian medical tourism providers should place greater emphasis on CRM and innovation in an era that requires continuous technological advancements, quickly changing machinery, and changing customer to succeed.

In this sense, service organizations recognize the potential of innovation for satisfying customers' needs and maintaining the competitive advantage (Hakimi, Triki, \& Hammami, 
2014; Lin, Chen, \& Chiu, 2010; Shriedeh \& Ghani, 2016b). The importance of innovation is not limited to business firms. Even in healthcare services, innovation has become an essential weapon to differentiate among services and products to survive in the global market (Hanaysha \& Hilman, 2015) and a critical key for success (Haikim et al., 2014).

Generally, scholars uniformly indicate that a significant and positive relationship exists between innovation and superior organizational performance (Ashraf, Kadir, Pihie, \& Rashid, 2014; Camisón \& López, 2010; Chen, Lin, \& Yang, 2011). Unfortunately, however, Battor and Battor (2010) have indicated that the failure rate of new products is between $40 \%$ and $75 \%$. Thus, healthcare providers must also manage the risks associated with product defects to remain competitive (Chen et al., 2011; Sivadas \& Dwyer, 2000). This requires understanding customer needs and tastes and, gathering external knowledge, and then translating these into innovative products (Akroush, Dahiyat, Gharaibeh, \& Abu-Lail, 2011; Darroch, 2005; Sin, Alan, \& Yim, 2005). In this sense, Customer Relationship Management (CRM) must perform effectively in transforming customer preferences and evolving needs into customer relationships and, thus, into innovative products/services using a better understanding of customers (Battor \& Battor, 2010; Chin et al., 2011; Lin et al., 2010). A good CRM strategy can develop innovation capabilities by improving relationships with customers, thus enhancing competitive advantages (Ghafari, Karjalian, \& Mashayekhnia, 2011; Lin et al., 2010; Ramani \& Kumar, 2008; Shriedeh \& Ghani, 2017).

Although the existing CRM literature has primarily acknowledged the relationship of CRM to performance, the empirical evidence to verify the relationship between CRM and innovation remains sparse. Also, prior CRM work has paid more attention to the management perspective and, insufficient attention has been addressed perspectives of medical tourist empirically (Akroush et al., 2011). Therefore, this study examines the one-to-one effect of CRM on innovation capabilities from the evaluations of medical tourists in Jordan.

The following section in this paper reviews the literature relating to the dimensionality of CRM and innovation capability. Next, research hypotheses are developed to test the relationships associated with several dimensions of both constructs, followed by the research design. Finally, the statistical results are discussed, and the limitations of the study are presented as well as directions of future research.

\section{Literature Review}

\subsection{Customer Relationship Management}

CRM refers to "the strategic use of information, processes, technology, and people to manage the customer's relationship with your company (marketing, sales, services, and support) across the whole customer life cycle" (Kincaid, 2003, p. 41). Kim, Choi, Qualls, also emphasize this view, and Park (2004) said that CRM is "based on the premise of integrating people, processes, and technology throughout the value chain to understand and deliver customer value better" (p. 634). In response to this integration notion, Sin et al. (2005) defined CRM as "a comprehensive strategy and process that enables an organization to identify, acquire, retain, and nurture profitable customers by building and maintaining long- 
term 'partnership' relationships with them" (p. 1266). According to Sin et al. (2005), CRM is a multidimensional construct that encompasses knowledge management, technology-based CRM, key customer focus, and CRM organization (Akroush et al., 2011). Following Sin et al.'s (2005) definition, Lin et al. (2010) suggested that CRM dimensions are information sharing, long- term relationships, customer involvement, technology-based CRM, and joint problem solving. Abdullateef, Mokhtar, and Yusoff (2010) said CRM is an “organization's ability to efficiently integrate people, process, and technology in maximizing positive relationships with both current and potential customers" (p.184). Accordingly, CRM includes four dimensions, which are customer orientation, CRM organization, technology-based CRM, and knowledge management. Wang and Feng (2008) viewed CRM as integration activities of knowledge management, relationship upgrading, interaction, and win-back "that focuses on establishing, maintaining, and enhancing long- term associations with selective customers to create superior value for the company and the customer" (p. 83).

Because various dimensions are associated with CRM, this study borrowed the most popular CRM dimensions as Jalali and Sardari (2015) and Lin et al. (2010) recommended, placing more emphasis on knowledge management. That was because information sharing is a sub-dimension of knowledge management. Thus, knowledge management, technology-based CRM, joint problem solving, long- term relationships, and customer involvement. These are discussed briefly below:

(1) Knowledge management: Generating, disseminating, transforming, and utilizing information related to customers are the basic activities of knowledge management and strongly related to CRM (Akroush et al., 2010; Shriedeh, 2019). Knowledge management effectively supports knowledge from the customer about their tastes and needs; sharing of customer knowledge within different departments to facilitate concerted actions; and taking proper actions corresponding to the knowledge sharing (Sin et al., 2005).

(2) Technology-based CRM: The remarkable advances in IS and IT supports the development of CRM (Gholami \& Rahman, 2012; Kincaid, 2003). This supportive role provides any business firm with the ability to gather, store, process, and share collected customer information in ways that significantly foster their ability to deliver customized products and, thus, to attract and retain customers (Gholami \& Rahman, 2012; Jalali \& Sardari, 2015). CRM calls for "information-intensive strategies" which use computer technology (e.g., database, data warehouse, data mining, and CRM software) in building and maintaining relationships, leveraging current technology and strictly connecting technology deployment to targeted business initiatives (Sin et al., 2005).

(3) Joint problem solving is collaborative work between two parties in which they jointly share the responsibility and find a mutually acceptable solution when a dispute occurs (Rubin, Pruitt, \& Kim, 1994).

(4) Trust and commitment are the two basic elements that commonly describe the longterm partnership relationship (Lin et al., 2010). Therefore, for maintaining successful 
relationships, involved parties must follow mutual goals and profits fairly and dependably (Handfield \& Bechtel, 2002). Also, Sin et al. (2005) have stated that, for maximizing long- term performance, a firm must build and maintain long- term and mutually valuable relationships with its target customers.

(5) Customer involvement: Collaboration with customers is an essential source of innovation activities (Vaisnore \& Petraite, 2011). This is grounded in the wealth of customers' knowledge due to their market and product experiences (Ritter \& Walter, 2003). Therefore, involving customers may lead to innovative ideas, market information, and new technologies that provide promising products and services and support future demands (Lin et al., 2010).

\subsection{Innovation Capabilities}

No globally accepted definition of innovation exists (Hakimi et al., 2014). As Damanpour and Schneider (2006) noted, "Innovation is studied in many disciplines and has been defined from different perspectives” (p. 216). For example, Du Plessis (2007) defined innovation based on knowledge management perspective as "the creation of new knowledge and ideas to facilitate new business outcomes, aimed at improving internal business processes and structures and to create market-driven products and services" (p. 21). This definition includes radical innovation and incremental innovation. For Rogers (2003) innovation is an "idea, practice, or project that is perceived as new by an individual or other unit of adoption" (p. 12). A similar definition asserts the degree of newness characteristic of innovation. Van de Ven (1986) said, "as long as the idea is perceived as new to the people involved, it is an 'innovation' even though it may appear to others to be an 'imitation' of something that exists elsewhere" (p. 592). This definition classifies innovation into technical innovation and administrative innovation. An exhaustive definition of innovation that is widely cited and vital for innovation type is that of the OECD Oslo Manual (2005), which said that innovation, is "the implementation of a new or significantly improved products, or processes, a new marketing method, or a new organizational method in business practices, workplace organization or external relations" (p. 46). This definition encompasses product innovation, process innovation, marketing innovation, and organizational innovation. Lastly, Lin et al. (2010) proposed five types of innovation model built on product innovation, process innovation, service innovation, administrative innovation, and marketing innovation.

However, this current study relies on five types of innovation that Lin et al. (2010) described, which are defined below:

(1) Product innovation is the introduction and development of a new good or notably improved in terms of characteristics or intended uses (Atalay, Anafarta, \& Sarvan, 2013). This entails improvements in technical specifications and functional characteristics.

(2) Process innovation is the implementation of new elements or improved methods of production and delivery (Lin \& Chen, 2007). This entails significant improvements in operational processes. 
(3) Service innovation is the employment of different innovation activities to foster customer satisfaction, such as the delivery of a new service or improved service (Lin et al., 2010).

(4) Administrative innovation refers to significant changes or improvements in organizational practice and administrative processes such as resource allocation and external relationships (Atalay et al., 2013).

(5) Marketing innovation is the employment of new marketing activity to better understanding customer needs such as product or service promotion and pricing strategy (Toma, Mihoreanu, \& Ionescu, 2014).

\section{Research Model and Hypotheses}

\subsection{Knowledge Management and Innovation Capabilities}

In general terms, knowledge management effectively maintains knowledge from the customer about their tastes and needs to provide novel ideas that can be innovative in terms of new products/services for better satisfying customers' preferences (Battor \& Battor; Darroch, 2005; Du Plessis, 2007). This view has also confirmed in the knowledge management literature. For example, Taherparvar, Esmaeilpour, and Dostar (2014) argued that knowledge management has a significant effect on innovation capability. Also, Revilla and Cury (2008) have demonstrated that knowledge management has a positive effect on product innovation (Allameh \& Abbas, 2010; Lee, Chang, Chien, Huang, \& Chen, 2010; Yang, 2011).

Further, Wastyn and Czarnitzki (2010) indicated that the management of knowledge influences technical innovation in terms of product innovation and process innovation. The studies of Ju, Li, and Lee (2006) and Tan and Nasurdin (2011) support this result. Generally, empirical studies have also confirmed the significant positive influence of knowledge management on service innovation (e.g., Shang, Lin, \& Wu, 2009), process innovation (Slavković \& Babić, 2013), marketing innovation (Lee et al., 2010), and administrative innovation (Ling \& Nasurdin, 2010; Tan \& Nasurdin, 2011; Slavković \& Babić, 2013). Accordingly, the following hypotheses are posited:

H1a. Knowledge management has a positive impact on product innovation.

H1b. Knowledge management has a positive impact on process innovation.

H1c. Knowledge management has a positive impact on service innovation.

H1d. Knowledge management has a positive impact on administrative innovation.

H1e. Knowledge management has a positive impact on marketing innovation.

\subsection{Customer Involvement and Innovation Capabilities}

Customer participation in new product development has been recognized as a key factor success in launching product innovation (Ritter \& Walter, 2003). Customer involvement in the early stages of new product innovation activities leads to the development more differentiated and enhanced products or services for specific target markets (Lin et al., 2010; 


\section{MInstitute ${ }_{\text {Mnk }}^{\text {Macrothink }}$}

Business and Economic Research

ISSN 2162-4860

2019, Vol. 9, No. 3

Tom et al., 2014). Also, customer participation in different product development activities encourages customers aids in organizational processes of product improvement techniques and designs to benefit the process innovation (Ritter \& Walter, 2003; Toma et al., 2014). Furthermore, through customer participation, firms that implement CRM are in a better position to predict market changes (Slater \& Narver, 1995) because of the ability to establish innovative management mechanisms (Toma et al., 2014). This kind of customer-oriented approach allows a customer to be involved in the formulation of marketing strategies (Dean \& Evan, 1994) and market trend evaluation (Lin \& Germain, 2004) thus, organizations are more committed to satisfying customer needs (Lin et al., 2010). In nutshell, empirical evidence has indicated the significant relationship between customer involvement and product innovation (Ghafari et al., 2011; Lin et al., 2010), marketing innovation (Ghafari et al., 2011; Lin et al., 2010), service innovation (Ghafari et al., 2011; Lin et al., 2010), process innovation, and administrative innovation (Ghafari et al., 2011). Thus, the following hypotheses are posited:

$\mathrm{H} 2 \mathrm{a}$. Customer involvement has a positive impact on product innovation.

H2b. Customer involvement has a positive impact on process innovation.

H2c. Customer involvement has a positive impact on service innovation.

H2d. Customer involvement has a positive impact on administrative innovation.

H2e. Customer involvement has a positive impact on marketing innovation.

\subsection{Long- term Relationship and Innovation Capabilities}

Because both involved parties are willing to ensure long- term relationships based on trust and commitment, loyalty enhancement is assured. Through strategic agreements and joint ventures, organizations are more prepared to invest in resource allocation activities to respond to changeable market needs. Thus, this involvement creates a higher chance of producing innovative products and processes (Battor \& Battor, 2012; Jack and Raturi, 2002) as well as more willingness to make changes in organizational infrastructure and culture to implement those innovative products (Maheshwari, Kumar, \& Kumar, 2006). Also, they are more likely to provide an acceptable pricing scenario and marketing strategies according to customer demands (Lin and Germain, 2004; Toma et al., 2014) and more likely to understand customer needs and promote steady customer contact environment, which, in turn, fosters service innovation (Zineldin, 1996). However, previous studies have indicated the significant relationship between long- term relationships and product innovation (Ghafari et al., 2011; Lin et al., 2010), process innovation (Ghafari et al., 2011; Lin et al., 2010). Besides, Ghafari et al. (2011) demonstrated that a significant relationship exists between long- term relationships and service innovation, marketing innovation, and administrative innovation. Thus, the following hypotheses are posited:

H3a. A long- term relationship has a positive impact on product innovation.

$\mathrm{H} 3 \mathrm{~b}$. A long- term relationship has a positive impact on process innovation. 
H3c. A long- term relationship has a positive impact on service innovation.

H3d. A long- term relationship has a positive impact on administrative innovation.

H3e. A long- term relationship has a positive impact on marketing innovation.

\subsection{Joint Problem Solving and Innovation Capabilities}

Joint problem solving is a key factor for market development and product success. Through collaborative problem solving, customers assist in solving issues related to product design or technical process, which, in turn, enhances product quality and introduce improvements to existing or potential processes, products, services, and markets (Huang and Chang, 2008). As expected, organizations also need to boost administrative techniques to ease the joint problem-solving process (Lin et al., 2010). Empirical evidence has shown a significant relationship between joint problem solving and product innovation, process innovation, administrative innovation, service innovation (Ghafari et al., 2011; Lin et al., 2010), and marketing innovation (Ghafari et al., 2011). Therefore, the following hypotheses are posited:

H4a. Joint problem solving has a positive impact on product innovation.

H4b. Joint problem solving has a positive impact on process innovation.

H4c. Joint problem solving has a positive impact on service innovation.

H4d. Joint problem solving has a positive impact on administrative innovation.

H4e. Joint problem solving has a positive impact on marketing innovation.

\subsection{Technology-based CRM and Innovation Capabilities}

IT and IS play a crucial role in the development of process innovation (Ghafari et al., 2011; Lin et al., 2010). Organizations with advanced IT are in a better position to transmit customer requests, insights, and preferences quickly to innovative and customized products (Akroush et al., 2011; Battor \& Battor, 2010), to implement different marketing strategies that targeted different customer groups (Dean \& Evan, 1994). Organizations deploying technology-based $\mathrm{CRM}$ are also in a better position to improve service quality and increase operational efficiency (Groznik, Kovacic, \& Trkman, 2008), customer satisfaction (Battor \& Battor, 2010), and enhances service innovation (Tom et al., 2014). Studies have indicated the significant relationship between technology-based CRM and product innovation, process innovation, administrative innovation, service innovation, and marketing innovation (Ghafari et al., 2011; Lin et al., 2010). Accordingly, the following hypotheses are posited:

H5a. Technology-based CRM has a positive impact on product innovation.

H5b. Technology-based CRM has a positive impact on process innovation.

H5c. Technology-based CRM has a positive impact on service innovation.

H5d. Technology-based CRM has a positive impact on administrative innovation.

H5e. Technology-based CRM has a positive impact on marketing innovation. 


\section{Research Design Methodology}

\subsection{Survey}

A questionnaire was distributed to 384 medical tourists who were systematically randomly selected from the top five private hospitals in Amman-Jordan. Every $4^{\text {th }}$ medical tourist in the selected hospitals was asked to participate in answering the survey. Three hundred six questionnaires were used for further analysis, yielding a response rate of $79.69 \%$. For content validity and the convenience of the measurements, a pilot study was conducted among a variety of professionals in this field, and 100 questionnaires were piloted among medical tourists of the selected hospitals. This process resulted in minor modifications on the wording and resolving double-barreled measurements.

\subsection{Measures}

The measurement scales for CRM and innovation capabilities were adapted based on the existing literature. For CRM, four items of knowledge management were based on Sin et al. (2005). Six items of a long- term relationship, three items of joint problem solving, and five items of customer involvement were based on Lin et al. (2010). Six items of technology-based CRM were based on Sin et al. (2005) and Lin et al. (2010). For innovation capabilities, six items of product innovation were based on Hanaysha, Hilman, and Abdul-Ghani (2014) and Shiau (2014). Five items of service innovation were based on Shiau (2014), and one item was added based on the pilot study. Three items of process innovation and four items of administrative innovation were based on the study of Wu and Hsieh (2015). Only four items of marketing innovation were borrowed from Lin et al. (2010). A 7-point Likert-type scale was used for all constructs.

\subsection{Statistical Methods}

This paper presented demographic characteristics in the first stage, and then exploratory factor analysis (EFA) with varimax rotation was implemented using SPSS v21 as the second stage. The third stage used confirmatory factor analysis through AMOS v21. Finally, regression analysis between CRM and innovation was conducted.

\section{Statistical Results}

\subsection{Descriptive Characteristics of Demographic Factors}

From the descriptive analysis, the results indicated that a large number of medical tourists treated in Jordan were men (55.6\%), were aged from 36 to 45 (28.8\%), held bachelor's degree $(48.0 \%)$, and were married $(66.7 \%)$. Also, more than half earned less than USD 1000 monthly and came from the Middle East, particularly Yemen (29.7\%).

\subsection{Exploratory Factor Analysis (EFA)}

The results of EFA for CRM yielded five factors with 21 measurement items. Three items were removed due to factor loading $<0.5$. The remaining items had loadings ranging from 0.577 to 0.849 . In addition, the Kaiser-Meyer-Olkin of sampling adequacy was $0.922>0.5$, and the eigenvalue per each factor was also above the recommended level $>1$. Five factors of 
CRM explained $71.819 \%$ of the total variance. Therefore, the factor analysis was proper for further analysis (Hair, Black, Babin, Anderson, \& Tatham, 2010). The results of EFA for innovation capability yielded five factors with 20 measurement items. Three items were removed due to factor loading $<0.5$. The remaining items had loadings ranging from 0.508 to 0.882. Also, the Kaiser-Meyer-Olkin of sampling adequacy was $0.925>0.5$, and the eigenvalue per each factor was also above the recommended level $>1$. Five factors of CRM explained $75.533 \%$ of the total variance. Therefore, the factor analysis was proper for further analysis (Hair et al., 2010).

\subsection{Confirmatory Factor Analysis (CFA)}

The findings of CFA for the CRM produced 17 items and indicated that the measures of the goodness-of-fit index exceeded the minimum requirement value and, thus, the guidelines were met. For example, the Chi-square value was 360.147 at $\mathrm{p}=0.000$, the GFI value was 0.893 , the AGFI value was 0.849 , the TLI value was 0.916 , the CFI value was 0.933 , and the RMSEA value was 0.079. Therefore, the factor analysis was proper for further analysis (Hair et al., 2010). Furthermore, the derived Cronbach's alpha of the product innovation (0.917), process innovation (0.875), administrative innovation (0.793), marketing innovation (0.749), and service innovation (0.913) indicates high-internal consistency of more than 0.70 (Hair et al., 2010). In addition, the factor loadings derived from CFA supports the convergent validity and construct validity because all loadings were above the threshold value of 0.5 , ranging from 0.504 to 0.967 ((Hair et al., 2010). Furthermore, the discriminant validity was also supported based on AVE values. The minimum AVE value (0.547) exceeded the threshold value of 0.5 (Byrne, 2010). Besides, the findings of CFA for the innovation capability produced 19 items and indicated that the measures of the goodness-of-fit index exceeded the minimum requirement value and, thus, the guidelines were met. For example, the Chi-square value was 438.052 at $\mathrm{p}=0.000$, the GFI value was 0.889 , the AGFI value was 0.851 , the TLI value was 0.931 , the CFI value was 0.943 , and the RMSEA value was 0.075 . Therefore, the factor analysis was proper for further analysis (Hair et al., 2010). Furthermore, the derived Cronbach's alpha of the knowledge management (0.848), long- term relationships $(0.800)$, customer involvement (0.852), technology-based CRM (0.800), and joint problem solving (0.887) indicate high-internal consistency above 0.70 (Hair et al., 2010). In addition, the factor loadings derived from CFA support the convergent validity and construct validity because all loadings were above the threshold value of 0.5 , ranging from 0.553 to 0.894 ((Hair et al., 2010). Furthermore, the discriminant validity was also supported based on AVE values. The minimum AVE value (0.621) exceeded the threshold value of 0.5 (Byrne, 2010)

\subsection{Regression Analysis}

For regression analysis between proposed constructs, multicollinearity was evaluated. Table 1 shows that the model was free of multicollinearity among independent variables because the values of tolerance were more than 0.10, and the values of VIF were below 10 (Hair et al., 2010). Also, the goodness-of-fit index was checked through the structural model. The results indicated a satisfactory model fit (Chi-square=1270.770, $\mathrm{p}=0.0$; TLI=0.905; CFI=0.916; $\mathrm{GFI}=0.835$; AGFI=0.802; RMSEA=0.062). Again, Table 1 shows the regression analysis 
results.

Table 1. Regression analysis results

\begin{tabular}{|c|c|c|c|c|c|c|c|}
\hline \multirow{3}{*}{\begin{tabular}{|l} 
\\
$\begin{array}{l}\text { Independent } \\
\text { variables }\end{array}$
\end{tabular}} & \multicolumn{5}{|c|}{ Innovation Capability } & \multirow{2}{*}{\multicolumn{2}{|c|}{$\begin{array}{l}\text { Collinearity } \\
\text { Statistics }\end{array}$}} \\
\hline & \multirow{2}{*}{$\begin{array}{c}\text { Product } \\
\beta\end{array}$} & \multirow{2}{*}{$\begin{array}{c}\text { Process } \\
\beta\end{array}$} & \multirow{2}{*}{$\begin{array}{c}\text { Service } \\
\beta\end{array}$} & \multirow{2}{*}{$\begin{array}{c}\text { Administrative } \\
\beta\end{array}$} & \multirow{2}{*}{$\begin{array}{c}\text { Marketing } \\
\beta\end{array}$} & & \\
\hline & & & & & & Tolerance & VIF \\
\hline $\begin{array}{l}\text { Knowledge } \\
\text { management }\end{array}$ & $1.492 * *$ & $1.768^{* *}$ & $1.612 * *$ & -0.853 & $1.393^{*}$ & 0.496 & 2.02 \\
\hline Customer involvement & $1.173 * *$ & $1.157 *$ & $1.572^{*}$ & $(-1.600)^{*}$ & $0.796 * *$ & 0.545 & 1.83 \\
\hline Long-term relationship & $3.874 *$ & $2.904 *$ & $4.313^{*}$ & $4.573^{*}$ & $2.953 *$ & 0.426 & 2.35 \\
\hline Joint problem solving & $3.913 * *$ & $3.243 * *$ & $5.103 * *$ & $2.721 * *$ & $4.807 * *$ & 0.519 & 1.93 \\
\hline $\begin{array}{l}\text { Technology-based } \\
\text { CRM }\end{array}$ & $1.924 * *$ & $1.663^{* *}$ & $2.516^{* *}$ & -1.048 & -2.325 & 0.686 & 1.46 \\
\hline
\end{tabular}

Notes: Significant at: $* \mathrm{p}=0.05$ and $* * \mathrm{p}=0.01$.

\subsubsection{Knowledge Management and Innovation Capabilities}

As shown in Table 1, the results indicated that knowledge management positively and significantly affected product innovation $(\beta=1.492$, t-value $=2.445, \mathrm{p}<0.01)$, process innovation $(\beta=1.768$, $\mathrm{t}$-value $=2.449, \mathrm{p}<0.01)$, service innovation $(\beta=1.612$, $\mathrm{t}$-value $=$ 2.313, $\mathrm{p}<0.01)$, and marketing innovation $(\beta=1.393$, $\mathrm{t}$-value $=2.782, \mathrm{p}<0.05)$; therefore, $\mathrm{H1a}, \mathrm{H} 1 \mathrm{~b}, \mathrm{H} 1 \mathrm{c}$, and H1e are supported. Differently, knowledge management was found to have an insignificant relationship with administrative innovation $(\beta=-0.853$, $\mathrm{t}$-value $=-1.713$, p > 0.05); hence, H1d is not supported.

\subsubsection{Customer Involvement and Innovation Capabilities}

The linkage between customer involvement and innovation capability was found to be significant and positive. For example, product innovation $(\beta=1.173$, t-value $=2.427, \mathrm{p}<$ $0.01)$, process innovation $(\beta=1.157$, t-value $=2.893, \mathrm{p}<0.05)$, service innovation $(\beta=1.572$, $\mathrm{t}$-value $=2.824, \mathrm{p}<0.05)$, and marketing innovation $(\beta=0.796$, $\mathrm{t}$-value $=2.029, \mathrm{p}<0.01)$. Customer involvement was also found to have a significant effect on administrative innovation, but negative $(\beta=1.600$, $\mathrm{t}$-value $=-2.784, \mathrm{p}<0.05)$; thus $\mathrm{H} 2 \mathrm{a}-\mathrm{H} 2 \mathrm{e}$ are supported.

\subsubsection{Long- term Relationship and Innovation Capabilities}

Long- term relationship has significant and positive effects on innovation capability at $\mathrm{p}<$ 0.05. Empirical evidence shows that long- term relationship was a significant predictor for product innovation $(\beta=3.874$, t-value $=3.218)$, process innovation $(\beta=2.904$, $\mathrm{t}$-value $=$ 2.947), service innovation $(\beta=4.313$, $t$-value $=3.128)$, administrative innovation $(\beta=4.573$, $\mathrm{t}$-value $=3.205)$, and marketing innovation $(\beta=2.953$, $\mathrm{t}$-value $=2.997)$; therefore, $\mathrm{H} 3 \mathrm{a}-\mathrm{H} 3 \mathrm{e}$ are also supported.

\subsubsection{Joint Problem Solving and Innovation Capabilities}

Joint problem solving was positively and significantly affected innovation capability at $\mathrm{p}$ 
$<0.01$. This reflection was shown on product innovation $(\beta=3.913$, $t$-value $=2.416)$, process innovation $(\beta=3.243$, t-value $=2.327)$, service innovation $(\beta=5.103$, t-value $=2.431)$, administrative innovation $(\beta=2.721$, $\mathrm{t}$-value $=2.286)$, and marketing innovation $(\beta=4.807$, $\mathrm{t}$-value $=2.406)$; accordingly, $\mathrm{H} 4 \mathrm{a}-\mathrm{H} 4 \mathrm{e}$ are confirmed.

\subsubsection{Technology-based CRM and Innovation Capabilities}

At the significance level $\mathrm{p}<0.01$, technology-based CRM was found to be positive effects on product innovation $(\beta=1.924$, $\mathrm{t}$-value $=1.978)$, process innovation $(\beta=1.663$, $\mathrm{t}$-value $=$ $1.998)$, and service innovation $(\beta=2.516$, t-value $=1.998)$; therefore, H5a, H5b, and H5C are supported. However, technology-based CRM did not significantly effect administrative innovation $(\beta=-1.048, \mathrm{t}$-value $=-1.471, \mathrm{p}>0.05)$ or marketing innovation $(\beta=-2.325$, t-value $=-1.940, \mathrm{p}>0.05)$; thus, H5d and H5e are not confirmed.

\section{Conclusion}

CRM is one of the most valuable sources associated with innovation capabilities and competitive advantage (Battor \& Battor, 2010; Lin et al., 2010; Shriedeh \& Ghani, 2016a, Toma et al., 2014). This study filled the literature gap and suggests that CRM and innovation are multidimensional concepts and provides support for the effects of several CRM dimensions on several innovation capabilities. This study indicates that the majority of the CRM activities positively contribute to specific capabilities of innovation.

The results show that effective knowledge management interacts in a way that enhances innovation capability. Through external collaboration like customers, organizations can get more innovative ideas, which, in turn, foster innovation capability. A similar result is found in the study of Jalali and Sardari (2015). Also, the results indicated that customers are less involved in administrative activities. Therefore, knowledge management was insignificantly related to administrative innovation.

Furthermore, this study has indicated that extensive customer involvement leads to the success of product and service development and enhancements in marketing activities. Ghafari et al. (2011) and Jalali and Sardari (2015) also support this result. However, customer participation has a negative influence on administrative innovation.

Consistent with Ghafari et al. (2011) and Jalali and Sardari (2015) observations, the results provide evidence for a positive effect between both joint problem solving and long- term relationship towards all types of innovation capability. Nonetheless, technology-based CRM has significant impacts on the development of only product innovation, process innovation, and service innovation. Ghafari et al. (2010), Jalali and Sardari (2015), and Lin et al. (2010) support this result. Technology-based CRM was not found to have a significant effect on administrative and marketing innovation. Overall, to achieve superiority in certain types of innovation, organizations must carefully integrate and align different CRM activities into practice.

This study has some limitations that can be used as guidelines for further future research. First, the data were collected from the perspectives of medical tourists only. However, the 
most recommended data-collection approach is to use multiple data collection methods (e.g., marketing managers). Second, this study is limited to the medical tourism industry in Jordan. Future studies are recommended to use data from different countries and different settings to increase the generalizability of the findings. Third, this study was based on a direct path between CRM and innovation, and future research is suggested to study the indirect and direct effect of CRM on organizational performance through innovation.

\section{References}

Abdullateef, A. O., Mokhtar, S. S., \& Yusoff, R. Z. (2010). The impact of CRM dimensions on call center performance. International Journal of Computer Science and Network Security, 10(12), 184-195.

Akroush, M. N., Dahiyat, S. E., Gharaibeh, H. S., \& Abu-Lail, B. N. (2011). Customer relationship management implementation: An investigation of a scale's generalizability and its relationship with business performance in a developing country context. International Journal of Commerce and Management, 21(2), 158-190.

https://doi.org/10.1108/10569211111144355

Ashraf, G., Kadir, S. A., Pihie, Z. A. L., \& Rashid, A. M. (2014). Relationship between organizational innovativeness types and organizational effectiveness in private universities in Iran. Journal of Studies in Education, 4(1), 142-153. https://doi.org/10.5296/jse.v4i1.4154

Atalay, M., Anafarta, N., \& Sarvan, F. (2013). The relationship between innovation and firm performance: An empirical evidence from Turkish automotive supplier industry. Procedia-Social and Behavioral Sciences, 75, 226-235.

https://doi.org/10.1016/j.sbspro.2013.04.026

Battor, M., \& Battor, M. (2010). The impact of customer relationship management capability on innovation and performance advantages: Testing a mediated model. Journal of Marketing Management, 26(9-10), 842-857. https://doi.org/10.1080/02672570903498843

Byrne. B. M. (2010). Structural equation modeling with Amos; Basic concepts, application and programming (2nd ed.). New York, NY: Routledge Taylor and Francis Group.

Camisón, C., \& López, A. V. (2010). An examination of the relationship between manufacturing flexibility and firm performance: The mediating role of innovation. International Journal of Operations \& Production Management, 30(8), 853-878. https://doi.org/10.1108/01443571011068199

Chen, R. H., Lin, R. J., \& Yang, P. C. (2011). The relationships between ECRM, innovation, and customer value-An empirical study. In Business Innovation and Technology Management (APBITM), 2011 IEEE International Summer Conference of Asia Pacific (pp. 299-302). IEEE.

Damanpour, F. \& Schneider, M. (2006). Phases of the adoption of innovation in organizations: Effects of environment, organization and top managers. British Journal of Management, 17(3), 215-36. https://doi.org/10.1111/j.1467-8551.2006.00498.x 


\section{Macrothink}

Business and Economic Research ISSN 2162-4860 2019, Vol. 9, No. 3

Darroch, J. (2005). Knowledge management, innovation and firm performance. Journal of Knowledge Management, 9(3), 101-115. https://doi.org/10.1108/14691930210435570

Dean, J. W., \& Evan, J. R. (1994). Total quality management, organization, and strategy. Minneapolis, MN: West Publishing.

$\mathrm{Du}$ Plessis, M. (2007). The role of knowledge management in innovation. Journal of Knowledge Management, 11(4), 20-29. https://doi.org/10.1108/13673270710762684

Farkouh, M. (2015). Healthcare resource guide: Jordan. [Online] Available:

http://export.gov/health/healthcarersourceguide/egmain_092005.asp

Ghafari, P., Karjalian, R., \& Mashayekhnia, A. (2011). Studying the relationship between different dimensions of CRM and innovation capabilities in Melli bank of Iran. World Academy of Science, Engineering and Technology, 2011, 906-910.

Gholami, S., \& Rahman, M. S. (2012). CRM: A conceptual framework of enablers and perspectives. Business and Management Research, 1(1), 96-105.

https://doi.org/10.5430/bmr.v1n1p96

Groznik, A., Kovacic, A., \& Trkman, P. (2008). The role of business renovation and information in e-government. The Journal of Computer Information Systems, 49(1), 81-89. https://doi.org/10.1080/08874417.2008.11645309

Hair, J. F., Jr., Black, W. C., Babin, B. J., Anderson, R. E., \& Tatham, R. L. (2010). Multivariate data analysis (7th ed.). Upper Saddle River, NJ: Pearson Prentice Hall.

Hakimi, W. B., Triki, A., \& Hammami, S. M. (2014). Developing a customer knowledge-based measure for innovation management. European Journal of Innovation Management, 17(3), 349-374. https://doi.org/10.1108/EJIM-02-2013-0019

Hanaysha, J., \& Hilman, H. (2015). Strategic effects of product innovation, service quality, and relationship quality on brand equity. Asian Social Science, 11(10), 56-72. https://doi.org/10.5539/ass.v11n10p56

Hanaysha, J., Hilman, H., \& Abdul-Ghani, N. H. (2014). Direct and indirect effects of product innovation and product quality on brand image: Empirical evidence from automotive industry. International Journal of Scientific and Research Publications, 4(11), 1-7. https://doi.org/10.5539/ass.v11n10p94

Handfield, R. B., \& Bechtel, C. (2002). The role of trust and relationship structure in improving supply chain responsiveness. Industrial Marketing Management, 31(4), 367-382. https://doi.org/10.1016/S0019-8501(01)00169-9

Huang, H. C., \& Chang, C. W. (2008). Embedded ties and the acquisition of competitive advantage. Journal of Intellectual Capital, 9(1), 105-121.

https://doi.org/10.1108/14691930810845830

IIe, F., \& Tigu, G. (2017). Medical tourism market trends - An exploratory research. Proceedings of the International Conference on Business Excellence, 11(1), 1111-1121. 
https://doi.org/10.1515/picbe-2017-0114

Jack, E. P., \& Raturi, A. (2002). Sources of volume flexibility and their impact on performance. Journal of Operations Management, 20(5), 519-548.

https://doi.org/10.1016/S0272-6963(01)00079-1

Jalali, S. M., \& Sardari, M. (2015). Study the effect of different aspects of customer relationship management (CRM) on innovation capabilities with mediator role of knowledge management (Case study: Mahram company). Mediterranean Journal of Social Sciences, $6(6$ S6), 343. https://doi.org/10.5901/mjss.2015.v6n6s6p343

Ju, T. L., Li, C. Y., \& Lee, T. S. (2006). A contingency model for knowledge management capability and innovation. Industrial Management and Data Systems, 106(6), 855-877. https://doi.org/10.1108/02635570610671524

Kim, J. W., Choi, J., Qualls, W., \& Park, J. (2004). The impact of CRM on firm-and relationship-level performance in distribution networks. Communications of the Association for Information Systems, 14, 632-52. https://doi.org/10.17705/1CAIS.01430

Kincaid, J. W. (2003), Customer relationship management: Getting it right! Upper Saddle River, NJ: Prentice Hall.

Lee, Y. J., Chang, L. Y., Chien, C. L., Huang, C. L., \& Chen, C. Y. (2010). The influence of knowledge management and marketing innovation strategies on marketing performance: $\mathrm{A}$ case study of a Taiwan funeral service company. Innovative Marketing, 6(2), 1-11.

Lin, C. Y. Y., \& Chen, M. Y. C. (2007). Does innovation lead to performance? An empirical study of SMEs in Taiwan. Management Research News, 30(2), 115-132.

https://doi.org/10.1108/01409170710722955

Lin, R. J., Chen, R. H., \& Chiu, K. K. S. (2010). Customer relationship management and innovation capability: An empirical study. Industrial Management \& Data Systems, 110(1), 111-133. https://doi.org/10.1108/02635571011008434

Lin, X., \& Germain, R. (2004). Antecedents to customer involvement in product development. European Management Journal, 22(2), 244-255. https://doi.org/10.1016/j.emj.2004.01.009

Ling, T. C., \& Nasurdin, A. Z. (2010). The influence of knowledge management effectiveness on administrative innovation among Malaysian manufacturing firms. Asian Academy of Management Journal, 15(1), 63-77.

Maheshwari, B., Kumar, V., \& Kumar, U. (2006). Optimizing success in supply chain partnerships. Journal of Enterprise Information Management, 19(3), 277-291.

https://doi.org/10.1108/17410390610658469

Noor, R. (2013). Outbound medical tourism from Bangladesh: Problems and solutions (Unpublished master's thesis). University of Greenwich, London, UK. [Online] Available: https://www.salauddinshospital.com/pdf/Outbound\%20Medical\%20Tourism\%20from\%20Ba ngladesh\%20-\%20Problems\%20and\%20Solutions.pdf 
OCDE (2005). The measurement of scientific and technological activities. Oslo manual. Guidelines for collecting and interpreting innovation data (3rd ed.). Organisation for Economic Co-operation and Development Eurostat, Paris. [Online] Available: https://www.tubitak.gov.tr/tubitak_content_files/BTYPD/kilavuzlar/Oslo_Manual_Third_Edi tion.pdf

PHA (2016). Medical tourism statistics. Amman. Jordan.

Ramani, G., \& Kumar, V. (2008). Interaction orientation and firm performance. Journal of Marketing, 72(1), 27-45. https://doi.org/10.1509/jmkg.72.1.027

Revilla, E., \& Cury, T. (2008). Antecedents and consequences of knowledge integration in product development. An empirical evidence. Working Paper No. WP08-13, IE Business School. https://doi.org/10.2139/ssrn.1134491

Ritter, T., \& Walter, A. (2003). Relationship-specific antecedents of customer involvement in new product development. International Journal of Technology Management, 26(5-6), 482-501. https://doi.org/10.1504/IJTM.2003.003419

Rogers, E. M. (2003). Diffusion of innovations (5th ed.). New York, NY: Free Press.

Rubin, J. Z., Pruitt, D. G., \& Kim, S. H. (1994). Social conflict: Escalation, stalemate, and settlement. New York, NY: McGraw-Hill.

Shang, S. S., Lin, S. F., \& Wu, Y. L. (2009). Service innovation through dynamic knowledge management. Industrial Management \& Data Systems, 109(3), 322-337.

https://doi.org/10.1108/02635570910939362

Shiau, H. C. (2014). The impact of product innovation on behavior intention: the measurement of the mediating effect of the brand image of Japanese anime dolls. Anthropologist, 17(3), 777-788. https://doi.org/10.1080/09720073.2014.11891492

Shriedeh, F. B. F. (2018). The role of customer relationship management, service quality and innovation as sources of brand equity development (Unpublished doctoral dissertation). Universiti Utara Malaysia, Kedah, Malaysia.

Shriedeh, F. B. (2019). Strategic factors for building brand equity: Jordan medical tourism. Journal the Messenger, 11(1A), 121-137.

https://doi.org/10.26623/themessenger.v11i1A.821

Shriedeh, F. B., \& Ghani, N. H. A. (2016a). Impact of innovation on the relationship between customer relationship management and brand equity in the medical tourism of Jordan. Journal of Research in Business, Economics and Management, 7(4), 1150-1158.

Shriedeh, F. B., \& Ghani, N. H. A. (2016b). Innovation's effect on brand equity: Insights from medical tourists. Journal of Asian Business Strategy, 6(8), 176-184.

https://doi.org/10.18488/journal.1006/2016.6.8/1006.8.176.184

Shriedeh, F., \& Ghani, N. H. (2017). Impact of customer relationship management on brand equity: Medical tourist perspective. Research Journal of Business Management, 11(1), 28-38. 
https://doi.org/10.3923/rjbm.2017.28.38

Sin, L. Y., Alan, C. B., \& Yim, F. H. (2005). CRM: Conceptualization and scale development. European Journal of Marketing, 39(11/12), 1264-1290.

https://doi.org/10.1108/03090560510623253

Sivadas, E., \& Dwyer, F. R. (2000). An examination of organizational factors influencing new product success in internal and alliance-based processes. Journal of Marketing, 64(1), 31-49. https://doi.org/10.1509/jmkg.64.1.31.17985

Slater, S.F., \& Narver, J.C. (1995). Market orientation and the learning organization. Journal of Marketing, 59(3), 63-74. https://doi.org/10.1177/002224299505900306

Slavković, M., \& Babić, V. (2013). Knowledge management, innovativeness, and organizational performance: Evidence from Serbia. Economic Annals, 58(199), 85-108. https://doi.org/10.2298/EKA1399085S

Taherparvar, N., Esmaeilpour, R., \& Dostar, M. (2014). Customer knowledge management, innovation capability, and business performance: A case study of the banking industry. Journal of Knowledge Management, 18(3), 591-610.

https://doi.org/10.1108/JKM-11-2013-0446

Tan, C. L., \& Nasurdin, A. M. (2011). Human resource management practices and organizational innovation: assessing the mediating role of knowledge management effectiveness. Electronic Journal of Knowledge Management, 9(2), 155-167.

Toma, M., Mihoreanu, L., \& Ionescu, A. (2014). Innovation capability and customer relationship management: a review. Economics, Management and Financial Markets, 9(4), 323-331.

Vaisnore, A., \& Petraite, M. (2011). Customer involvement into open innovation processes: A conceptual model. Social Sciences, 73(3), 62-73. https://doi.org/10.5755/j01.ss.73.3.793

Van de Ven, A. H. (1986). Central problems in the management of innovation. Management Science, 32(5), 590-607. https://doi.org/10.1287/mnsc.32.5.590

Wang, Y. G., \& Feng, H. (2008). CRM capability in service industries: Conceptualization and scale development. In Proceedings of the IEEE International Conference on Service Operations and Logistics and Informatics (pp. 83-88). Beijing, October 12-15.

Wastyn, A., \& Czarnitzki, D. (2010). Does professional knowledge management improve innovation performance at the firm level? ZEW - Centre for European Economic Research Discussion Paper No. 09-067. https://doi.org/10.2139/ssrn.1504068

Wu, I. L., \& Hsieh, P. J. (2015). Hospital innovation and its impact on customer-perceived quality of care: A process-based evaluation approach. Total Quality Management \& Business Excellence, 26(1-2), 46-61. https://doi.org/10.1080/14783363.2013.799332

Yang, D. (2011). The effect of knowledge management on product innovation-Evidence from Chinese software outsourcing vendors. IBusiness, 3(1), 16-22. 
https://doi.org/10.4236/ib.2011.31003

Zineldin, M. (1996). Bank-corporate client "partnership" relationship: Benefits and life cycle. International Journal of Bank Marketing, 14(3), 14-22.

https://doi.org/10.1108/02652329610113135

\section{Copyright Disclaimer}

Copyright for this article is retained by the author(s), with first publication rights granted to the journal.

This is an open-access article distributed under the terms and conditions of the Creative Commons Attribution license (http://creativecommons.org/licenses/by/3.0/). 